\title{
Effect of Cooperative Membership on the Economic Empowerment of Women in Osun State of Nigeria
}

\author{
Taiwo Abdulahi Olabisi ${ }^{1, ~}$, Udunze Ugochukwu MacDonald ${ }^{2}$, Agbasi Obianuju Emmanuela ${ }^{1}$ \\ ${ }^{1}$ Department of Cooperative Economics and Management, Nnamdi Azikiwe University, Awka, Anambra State of Nigeria \\ ${ }^{2}$ Department of Public Administration sciences, Nnamdi Azikiwe University, Awka, Anambra State of Nigeria
}

Email address:

taiwo2020@yahoo.com (T. A. Olabisi), Udunze_ugo@yahoo.com (U. U. M. Donald), ujayagbasi@yahoo.con (A. O. Emmanuela)

\section{To cite this article:}

Taiwo Abdulahi Olabisi, Udunze Ugochukwu MacDonald, Agbasi Obianugu Emmanuela. Effect of Cooperative Membership on the Economic Empowerment of Women in Osun State of Nigeria. International Journal of Business and Economics Research.

Vol. 4, No. 2, 2015, pp. 21-29. doi: 10.11648/j.ijber.20150402.11

\begin{abstract}
Cooperative societies are organizations that have primary aim of providing needs of their members and enhance the quality of their members' livelihood. As such the study examined the effect of cooperative membership on the economic empowerment of women in Osun State of Nigeria. Data were obtained from 375 women cooperators across two senatorial zones of Osun State. Data obtained were analyzed with both descriptive statistics and inferential model of regression, T-test, ANOVA non parametric correlation test as well post - hoc test. Evidence from the study revealed that socioeconomic variables of the respondents are determinant factor for their membership in cooperative society. It was also revealed that women cooperative societies in Osun State are involved in different economic empowerment activities that are accessible and capable of empowering women in Osun State. Findings also revealed that economic empowerment activities of women cooperatives have positive effects on the level of entrepreneurial skills acquired by the women cooperators in Osun State. Therefore, in a bid to strengthen the economic empowerment efforts of women cooperative, the following recommendations are made necessary, the cooperative incorporate adult education as part of their empowerment programme. The cooperative should seek for more innovative skills and programmes that will boost economic status of the women cooperators. Since cooperative has membership effect on income level women should be encourage to join cooperative society if they want to improve their livelihood. Finally, extensions service should be provided with competent facilitators.
\end{abstract}

Keywords: Cooperative Membership, Women, Economic Empowerment

\section{Introduction}

Organizations such as Cooperative societies play an important role in facilitating women empowerment because they can address both economic and socio-cultural factors that perpetuate gender discrimination.

Economic Empowerment represents the transformation of power relations throughout society; increased wellbeing, community development, self sufficiency, expansion of individual choices and capacities for self reliance (Karubi 2006). In a similar manner, Kabeer (2001) sees women empowerment as the process which women take control and ownership of their lives through the expansion of their choices. Recognizing women empowerment is very vital to the overall progress in development as it ensures that women have the ability to shape their own security and foster effective participation in socio economic inclusion. Women empowerment is essential because in most cases women are responsible for their children as such empowering women are empowering the society at large.

Cooperative model can be used as a breeding ground to empower women economically by enhancing their specific knowledge and capacities. This is possible because cooperatives are business owned and controlled by the people who use them and it differ from other business because they are member owned and operated for the benefit of members, rather than earn profits for investors United States Department of Agriculture (USDA, 2005). Although cooperative is viewed as an organization for the promotion of economic interests of its members, it does not confine itself only to the economic aspect but also permeates the social aspect of life and aims at establishing a new democratic social order based on freedom and equality, where people live in harmony, caring and sharing like a family, where there is unity of spirit and common economic bond. According to Aregawi and Hailaslasie (2013) 
they believed that cooperative can create a safe environment where women increase their self confidence, identify their own challenges, make decisions and manage risks. And as a result, women are economically empowered and become active agents of change, entrepreneurs and promoters of social transformation who can improve their own lives and those of their community.

Since cooperatives are based on values of self-help, democracy, equality, equity and solidarity, they play particularly a strong role in empowering women, especially in developing countries like Nigeria (Nippierd 2002). Cooperatives allow women who might have been isolated and working individually to bind together and creates economies of scale as well as increase their own bargaining power in the competitive market. According to Green retrieved from Wikipedia (2014), cooperative businesses have done so much to give women sense of political, social and economic inclusion.

In spite of the advantages of the model (cooperatives), women participation in the economy and leadership position is very low, and women membership in Africa accounts for less than 30 percent and their participation declines for upper positions (Majurin, cited in Aregawi and Haileslasie, 2013).

Empowering women is empowering the society at large. The global statistics shows that women are in charge of $60-$ 80 percent of world's work force and produce 50 percent of food (World Bank, 2005). Despite the fact that their contributions are significant, they still have limited economic advantage and access to productive resources (Lawless; Hutchison; Schuler; Dean and Martins 2006; Mayroux, 2009).Lack of productive resources has been found to have gender underpinning in Nigeria. For instance, findings from the poverty and development study conducted by the World Bank and DFID in Nigeria using participatory poverty assessment method, indicate that consequences of being a woman in Nigeria include amongst others, the likelihood of having limited coping strategies, safety nets and constantly living with a sense of insecurity (World Bank, 1999).

The inference from the above statement shows that women most times lack productive resources such as capital, land, input and supplies. Despite the essential economic and social roles performed by women, they have significantly less access to financial, physical and social assets than men do, fewer opportunities to improve their knowledge and skills and less voice in public decision making (Chrissy -King, 2006).

According to IFAD in Onugu (2009), women own less than $2 \%$ of all land and receive only $5 \%$ of extension services worldwide. It is estimated that women in Africa receive less than $10 \%$ of all credit going to small farmers and a mere $1 \%$ of total credit going to the agricultural sector.

However, according to Aregawi and Haileslaise (2013) agreed that record has shown a number of approaches to development have been employed by government, developmental agencies, non-governmental organization to solve the socio-economic ills of the third world. However, these approaches failed to achieve their goals partly because they completely ignored women and their contribution to the efforts of development (Easter 2009).

Similarly, many studies (Ihenacho, et al 2012; Oyeniyi, 2013, Awotide, 2012) have been conducted in Nigeria in a bid to empower women, but the efforts and roles of women cooperative societies for instance in income generation and entrepreneurial skills acquisition have not been well researched and documented in Osun State, thus, leaves a gap and indeed necessitated the interest to conduct this study in order to ascertain the effort of cooperative on women empowerment in Osun State. As such, joining cooperative society (membership) will eventually empower women in Osun State by improving their income, and entrepreneurial skills through various empowerment activities of women cooperative societies in Osun State. This is the focus of the study.

\subsection{Objectives of the Study}

The broad objective of this study is to assess the effects of cooperative membership on women economic empowerment in Osun State. The specific objectives are to;

1. examine the socio economic status of the women cooperative members;

2. identify the economic empowerment activities of the cooperative societies that are channeled towards economic empowerment of the women cooperators;

3. Assess the effect of cooperative membership on the level of entrepreneurial skills acquired by women cooperators;

4. Compare the level of women cooperators' income before and after joining their society; and

5. Identify constraints that hinder the economic empowerment of women cooperators and make recommendations that will strengthen women economic empowerment through women cooperative societies' in Osun State.

\subsection{Hypotheses of the Study}

$\mathrm{H}_{01}$ : The socioeconomic characteristics of women cooperators are not significant factor for their membership cooperative society.

$\mathrm{H}_{02}$ : Based on cooperative membership experience, the opinion of the women cooperators do not differ significantly on the economic empowerment activities of their cooperative societies.

$\mathrm{H}_{03}$ : There is no significant relationship between entrepreneurial skills acquired by women cooperators and cooperative economic empowerment activities.

$\mathrm{H}_{04}$ : There is no significant disparity in annual income level of women cooperators when compare before and after their membership in cooperative society.

\subsection{Theoretical Framework}

The theoretical framework for this study was anchored on theory of collective economic empowerment. This is a branch of empowerment theory that was propounded by Brazilian humanitarian and educator, Freire in 1973retrieved from google.com (2014), where he suggested a plan for liberating 
the oppressed of the world. The theory of empowerment is not only concerned with the process of empowerment but also with result that can produce greater access to resources and power for the excluded group (e.g. women).

Meanwhile collective economic empowerment theory was developed by staples in 1990 and he affirmed that collective economic empowerment develops when people join in action to overcome obstacles and attain social change.

\subsection{Tenets of Collective Economic Empowerment Theory}

The theory was built on the following tenets:

1. The notion of collective economic empowerment is referring to belonging to the social network of peers and an emphasis on autonomy while being part of the collective social solidarity vis-à-vis establishment;

2. A collective belonging; involvement in; and control over organization in the community;

3. Collective economic empowerment involved creating a sense of community among people that will increase their ability to work together; problems solving and make group decisions for social change. This is also called social cohesion and a sense of personal freedom.

\subsection{Premise for the Adoption and Application of the Theory}

Collective economic empowerment is relevant and considered most appropriate for this study because of the following premises:

1. Collective economic empowerment was built on the basis of people coming together and form autonomous group with collective interest. This basis of collective empowerment is related to the cooperative society where people of common interest voluntarily come together in other to improve their livelihood/wellbeing through jointly owned investment. This premise is supported with ICA 1995 cooperative principles of open and voluntary membership and autonomous and independent association of persons with common interest.

2. The theory is also relevant to the study because it encourages members' active involvement and participates collectively in the economic empowerment activities of cooperative society. As such, this will give the members sense of belonging and control over their investment. Meanwhile, this premise is also supported and affirmed by the ICA 1995 cooperative principles of members' economic participation and democratic member control.

3. Lastly, collective economic empowerment theory creates sense of community that increases the ability of the cooperative members to work together collectively and participate in group decision making process. Therefore, this will boost cooperative members self confidence, self reliant and self esteem within their community.

Conclusively, the theory was designed to empower people economically by working together, and women cooperatives in Osun State are making efforts to give the women cooperators economic inclusion through cooperative various economic empowerments activities like credit facilities; employment, training etc.

\section{Research Method}

The study population as informed by the office of Director of Cooperative Osun State (2014). This consists of all the six hundred and twenty one (621) registered and functional women based cooperative societies with 40,698 membership strength in Osun State. This population is further divided into the three senatorial zones, Osun south senatorial zone; Osun north senatorial zone and Osun central senatorial zone.

The population was too large to study; as such the researchers adopted multistage sapling technique to get a concise sample size that will represent the population. Therefore, cluster and judgmental non random sampling method were used to select two (2) local government areas each from the three (3) senatorial zones in Osun State. These local government areas, were purposively selected based on the accessibility, convenience, available resources and time.

The data from the study was analyzed with both descriptive and inferential statistics. The descriptive statistics was used to analyze the five objectives formulated. The descriptive include scale analysis of five points with threshold (mean) of 3.0. That is any variable that is equal or greater than 3.0 was considered appropriate other than that was inappropriate. Also simple percentage, frequency tables and mean employed as part descriptive statistics. The inferential statistics was used to make affirm or reject the hypotheses of the study. As hypothesis one was analysed with regression and ANOVA in order to know how members opinion differ on economic empowerment ability of cooperative also hypothesis two was analysed with post- hoc test so as to know the relationship between business activities of cooperative, and entrepreneurial skills development.

\section{Data Analysis and Presentation}

\subsection{Socioeconomic Status of the Women Cooperators}

Table 1. Distribution of Responses on the Socioeconomic Characteristics.

\begin{tabular}{lllll}
\hline Socioeconomic Factors of Women Cooperators & Frequency $\mathbf{n}=$ & $\mathbf{\%}$ & Min. & Max \\
\hline Age (Year) & - & - & $18 \mathrm{yrs}$ & \\
MARITAL STATUS: & & & & Mean $(\overline{\mathbf{x}})$ \\
Married & 195 & 52 & - & - \\
Otherwise & 180 & 48 & - & - \\
Years of formal education & - & - & $0 \mathrm{yr}$ & - \\
OCCUPATION: & & & - \\
Farming & 54 & 14.4 & - \\
\hline
\end{tabular}




\begin{tabular}{llllll}
\hline Socioeconomic Factors of Women Cooperators & Frequency $\mathbf{n}=$ & $\mathbf{\%}$ & Min. & Max & Mean $(\overline{\mathbf{x}})$ \\
\hline Trading & 150 & 40.0 & - & - & - \\
Artisan/craftsmanship & 100 & 26.66 & - & - & - \\
Civil; servant & 53 & 14.13 & - & - & - \\
Retiree & 12 & 3.2 & - & - & - \\
Estimate income per annum (N) & - & - & $<100,000$ & $\geq 5$ million & 184.334 \\
Years of cooperative membership experience & - & - & $-1 \mathrm{yr}$ & $>21 \mathrm{yrs}$ & $6.94 \mathrm{yrs}$ \\
MEMBERSHIP STATUS: & & & & - \\
Management committee member & 24 & 6.4 & - & - & - \\
President & 5 & 1.333 & - & - & - \\
Vice president & 18 & 4.80 & - & - & - \\
Secretary & 43 & 11.46 & - & - & - \\
Financial secretary & 24 & 6.4 & - & - & - \\
Treasurer & 7 & 1.8 & - & - & - \\
Ordinary member & 278 & 74.133 & - & - & - \\
\hline
\end{tabular}

Source: Field Survey, October, 2014

The socioeconomic profile of women cooperators was displayed in the above table 1 , and the result revealed that majority of the women are still in their active and productive stage with average age of 43.61years, while most of them were married $(52 \%)$. The table also revealed that most of the women posed the basic (FSLC and SSCE) educational qualification as their average years of formal education is 8.6years. This indicated that women cooperators were literate to an extent. The result from the table also shows that women are involved in gainful occupation within the informal sector of the economy. This included, farming (14.4\%); trading (40\%); and artisan/craftsmanship (26.6\%) and their annual income rang from $\$ 100,000-\$ 500,000$ (57\% with average income of $\$ 184$, 336. Meanwhile, most of the women cooperators have been holding cooperative membership for about 11years to 15 years $(32.8 \%)$ with average membership experience of 6.94years.

\subsection{Test of Hypothesis One $\left(\mathrm{H}_{01}\right)$}

$\mathrm{H}_{01}$ : The socioeconomic characteristics of women cooperators are not significant factor for their membership cooperative society.

$\mathrm{H}_{\mathrm{A} 1}$ : The socioeconomic characteristics of women cooperators are significant factor for their membership in cooperative society.

Therefore, the socioeconomic table was subjected to regression analysis and the result was presented in the table 2 below:

Using Regression Approach, we have:

The independent variables are the socio-economic factors which include age (x1), marital status (x2), education (x3), occupation ( $\mathrm{x} 4)$, income (x5), membership experience $(\mathrm{x} 6)$, household size (x7), and membership status (x8).

\subsection{Regression Analysis: $y$ Versus $x i, x 2, x 3, x 4, x 5, x 6, x 7$, $x 8$}

The regression equation is

$$
\begin{gathered}
\mathrm{y}=0.016+0.043 \mathrm{xi}+0.022 \times 2+0.005 \times 3+0.024 \times 4+ \\
0.0011 \times 5+0.0053 \times 6+0.0103 \times 7+0.016 \times 8
\end{gathered}
$$

Table 2. Regression Analysis Result with SPSS version 2.

\begin{tabular}{llllll}
\hline Predictor & Coef & SE Coef & T & P & Remarks \\
\hline Constant & 0.016 & 0.0545 & 3.22 & 0.000 & (significant) \\
X1 & 0.043 & 0.0552 & 2.54 & 0.004 & (significant) \\
x2 & 0.022 & 0.0001 & 4.16 & 0.000 & (significant) \\
x3 & 0.005 & 0.0034 & 2.43 & 0.018 & (significant) \\
x4 & 0.024 & 0.0016 & 4.26 & 0.000 & (significant) \\
x5 & 0.0011 & 0.0061 & 3.13 & 0.020 & (significant) \\
x6 & 0.0053 & 0.0053 & 2.83 & 0.007 & (significant) \\
x7 & 0.0103 & 0.0001 & 2.25 & 0.027 & (significant) \\
x8 & 0.016 & 0.0055 & 0.27 & 0.012 & (significant) \\
\hline
\end{tabular}

$\mathrm{R}-\mathrm{Sq}=79.4 \% \mathrm{R}-\mathrm{Sq}(\mathrm{Adj})=74.7 \%$

The above result implies that $74.7 \%$ (adjusted $\mathrm{R}^{2}$ ) of variation in dependent variable (cooperative membership) was caused (explained) by the independent variables (age; marital status, years of formal education; occupation; income, years of experience, household size and members status.

Table 3. Summary Result of Analysis of variance.

\begin{tabular}{llllll}
\hline Analysis of Variance & \multicolumn{1}{l}{ SS } & F & P \\
\hline Source & DF & SS & MS & & \\
\hline Regression & 7 & 65.0231 & 9.2890 & 527.78 & 0.000 \\
Residual Error & 368 & 6.5321 & 0.0176 & & \\
Total & 375 & 71.5552 & & & \\
\hline
\end{tabular}

The p-value of the model is less than 0.05 which implies the model is significant at 5\% level of significant. As such the null hypothesis was rejected while the alternate was accepted. Therefore, the researcher concluded that socioeconomic characteristics of the respondents (women) are significant factor for their membership in cooperative society 


\subsection{Economic Empowerment Activities of the Cooperative Society that are Accessible to Women Cooperators}

Table 4. Distribution of Responses on the Economic Empowerment Activities of Cooperatives Rendered to Women.

\begin{tabular}{|c|c|c|c|}
\hline S/No & Economic Empowerment Activities & Mean $(\overline{\mathbf{x}})$ & Decision \\
\hline i. & Credit services delivery to members & 4.044 & Agree \\
\hline ii. & Collective processing of farm produce & 3.014 & Agree \\
\hline iii. & Product input supply & 4.050 & Agree \\
\hline iv. & $\begin{array}{l}\text { supply of members household and } \\
\text { consumer goods }\end{array}$ & 3.726 & Agree \\
\hline v. & $\begin{array}{l}\text { Leadership training and adult } \\
\text { education }\end{array}$ & 3.714 & Agree \\
\hline vi. & Health care service delivery & 4.020 & Agree \\
\hline vii. & Job opportunities for members & 3.880 & Agree \\
\hline viii. & Skill acquisition programmes & 3.778 & Agree \\
\hline ix. & Savings mobilization & 3.714 & Agree \\
\hline $\mathrm{x}$. & Business capital mobilization & 3.856 & Agree \\
\hline \multirow[t]{2}{*}{ xi. } & Advisory and advocacy services & 4.108 & Agree \\
\hline & Grand mean $(\overline{\mathrm{x}})$ & 3.809 & Agree \\
\hline
\end{tabular}

Source: Field Survey October, 2014

In the table 4 above, the result from the table was deduced from 5 point likert scale analysis with weighted mean of 3.0. That is, any economic empowerment activities variables that is less than 3.0 was considered negative (disagree) while those economic empowerment activities variables of women cooperative that scored above or equal 3.0 was considered to be positive, as such, the respondents agreed that those activities are accessible to them. Therefore, the grand mean of 3.809 indicated that most of women cooperators agreed that the economic empowerment activities of cooperative are accessible to them. Some of these economic empowerment activities include micro credit services delivery (4.044); collective processing (3.014); skills acquisition programme (3.778); capital mobilization (3.85) and savings mobilization (3.714)

Meanwhile, this result corroborates the result of Smith and Wills, (2012); Aregawi and Haileslasie (2013) where they revealed that, women join cooperative so as to have access to micro credit facilities, vocational training and other socioeconomic empowerment programmes like fish processing, honey processing.

\subsection{Test of Hypothesis Two $\left(\mathrm{H}_{02}\right)$}

$\mathrm{H}_{02}$ : Based on cooperative membership experience, the opinion of the women cooperators do not differ significantly on the economic empowerment activities of their cooperative societies.

$\mathrm{H}_{\mathrm{A} 2}$ : Based on cooperative membership experience, the opinion of the women cooperators differ significantly on the economic empowerment activities of their cooperative societies.

Therefore, in order to affirm or reject the hypothesis statement was subjected to ANOVA test and Post-Hoc tests and the result are presented in the tables below:

Testing the opinion of cooperators based on their membership years of experience on economic empowerment activities, we have the following observations;

Table 5. Observation Table Summary.

\begin{tabular}{|c|c|c|c|c|c|c|c|c|c|c|c|}
\hline \multicolumn{12}{|c|}{ Cooperative Economic Empowerment Activities } \\
\hline Years of membership & 1 & 2 & 3 & 4 & 5 & 6 & 7 & 8 & 9 & 10 & 11 \\
\hline $\mathrm{A}(1-5 \mathrm{yrs})$ & 3.94 & 3.76 & 3.99 & 4.33 & 3.76 & 4.16 & 3.76 & 4.33 & 3.76 & 4.16 & 4.33 \\
\hline $\mathrm{B}(6-10 \mathrm{yrs})$ & 3.62 & 4.16 & 4.23 & 3.99 & 4.33 & 4.05 & 3.99 & 3.99 & 3.62 & 4.05 & 3.99 \\
\hline C (11 - 15yrs $)$ & 4.33 & 4.05 & 4.11 & 2.87 & 3.87 & 4.33 & 3.76 & 2.87 & 3.76 & 3.99 & 2.87 \\
\hline $\mathrm{D}(11-20 \mathrm{yrs})$ & 3.99 & 3.95 & 3.65 & 3.76 & 4.10 & 3.99 & 3.62 & 3.76 & 4.10 & 4.23 & 3.62 \\
\hline E above 20yrs & 4.34 & 4.33 & 2.65 & 3.62 & 4.04 & 2.87 & 3.76 & 3.62 & 4.04 & 4.11 & 3.76 \\
\hline
\end{tabular}

Source: Field survey, 2014

Using Analysis of Variance at 5\% level of significance

Table 6. Observations.

\begin{tabular}{|c|c|c|c|c|c|c|c|c|}
\hline \multicolumn{9}{|c|}{ Descriptive } \\
\hline \multicolumn{9}{|l|}{ Obs } \\
\hline & \multirow{2}{*}{$\mathbf{N}$} & \multirow{2}{*}{ Mean } & \multirow{2}{*}{ Std. Deviation } & \multirow{2}{*}{ Std. Error } & \multicolumn{2}{|c|}{ 95\% Confidence Interval for Mean } & \multirow{2}{*}{ Minimum } & \multirow{2}{*}{ Maximum } \\
\hline & & & & & Lower Bound & Upper Bound & & \\
\hline 1.00 & 11 & 4.0255 & .24594 & .07415 & 3.8602 & 4.1907 & 3.76 & 4.33 \\
\hline 2.00 & 11 & 4.0018 & .21945 & .06617 & 3.8544 & 4.1492 & 3.62 & 4.33 \\
\hline 3.00 & 11 & 3.7100 & .57186 & .17242 & 3.3258 & 4.0942 & 2.87 & 4.33 \\
\hline 4.00 & 11 & 3.8882 & .21554 & .06499 & 3.7434 & 4.0330 & 3.62 & 4.23 \\
\hline 5.00 & 11 & 3.7400 & .54769 & .16513 & 3.3721 & 4.1079 & 2.65 & 4.34 \\
\hline Total & 55 & 3.8731 & .40250 & .05427 & 3.7643 & 3.9819 & 2.65 & 4.34 \\
\hline
\end{tabular}


Table 7. Observationsof ANOVA Result.

\begin{tabular}{llllll}
\hline Obs & & & & \\
\hline & Sum of Squares & df & Mean Square & F & Sig. \\
\hline Between Groups & .928 & 4 & .232 & 1.483 & .222 \\
Within Groups & 7.821 & 50 & .156 & & \\
Total & 8.748 & 54 & & & \\
\hline
\end{tabular}

Table 8. Post Hoc Tests.

\begin{tabular}{|c|c|c|c|c|c|c|}
\hline \multirow{2}{*}{ (I) factors } & \multirow{2}{*}{ (J) factors } & \multirow{2}{*}{ Mean Difference (I-J) } & \multirow{2}{*}{ Std. Error } & \multirow{2}{*}{ Sig. } & \multicolumn{2}{|c|}{ 95\% Confidence Interval } \\
\hline & & & & & Lower Bound & Upper Bound \\
\hline \multirow{4}{*}{1.00} & 2.00 & .02364 & .16864 & .889 & -.3151 & .3624 \\
\hline & 3.00 & .31545 & .16864 & .067 & -.0233 & .6542 \\
\hline & 4.00 & .13727 & .16864 & .420 & -.2014 & .4760 \\
\hline & 5.00 & .28545 & .16864 & .097 & -.0533 & .6242 \\
\hline \multirow{4}{*}{2.00} & 1.00 & -.02364 & .16864 & .889 & -.3624 & .3151 \\
\hline & 3.00 & .29182 & .16864 & .090 & -.0469 & .6305 \\
\hline & 4.00 & .11364 & .16864 & .504 & -.2251 & .4524 \\
\hline & 5.00 & .26182 & .16864 & .127 & -.0769 & .6005 \\
\hline \multirow{4}{*}{3.00} & 1.00 & -.31545 & .16864 & .067 & -.6542 & .0233 \\
\hline & 2.00 & -.29182 & .16864 & .090 & -.6305 & .0469 \\
\hline & 4.00 & -.17818 & .16864 & .296 & -.5169 & .1605 \\
\hline & 5.00 & -.03000 & .16864 & .860 & -.3687 & .3087 \\
\hline \multirow{4}{*}{4.00} & 1.00 & -.13727 & .16864 & .420 & -.4760 & .2014 \\
\hline & 2.00 & -.11364 & .16864 & .504 & -.4524 & .2251 \\
\hline & 3.00 & .17818 & .16864 & .296 & -.1605 & .5169 \\
\hline & 5.00 & .14818 & .16864 & .384 & -.1905 & .4869 \\
\hline \multirow{4}{*}{5.00} & 1.00 & -.28545 & .16864 & .097 & -.6242 & .0533 \\
\hline & 2.00 & -.26182 & .16864 & .127 & -.6005 & .0769 \\
\hline & 3.00 & .03000 & .16864 & .860 & -.3087 & .3687 \\
\hline & 4.00 & -.14818 & .16864 & .384 & -.4869 & .1905 \\
\hline
\end{tabular}

Obs - Observation

LSD - Least significance difference

The post Hoc test using the least significant difference shows the closeness of the mean response of each group. The higher the sig. value, the closer the mean difference of the groups compared, although the difference is insignificant as the p-value of the test is 0.222 which is greater than 0.05 .

Conclusion: the p-value of the test is greater than 0.05 which is an indication of the existence of enough evidence to accept the null hypothesis and conclude that the opinion of women cooperators do not significantly differ on the economic empowerment ability of cooperative through their business activities.

\subsection{Level of Entrepreneurial Skills Acquired by Women Cooperators}

The table 9 above result revealed that outcome of responses on the level of entrepreneurial skills acquired by women on 5 point scale analysis with threshold of 3.0. That is, any variable $\geq 3.0$ was considered effective while otherwise is ineffective. Meanwhile, the grand mean $(\overline{\mathrm{x}}=$ 4.128) of the variables give enough evidence that, being a member of cooperative society have effectively contributed to the acquisition of entrepreneurial skills among women cooperators in Anambra State. These entrepreneurial skills include training in soap and cream production (3.65); tailoring and hair salon training (4.01); palm oil processing and production (3.76); training on how to establish and manage small business (4.32); fish farm and fish production skills (4.26).

Table 9. Distribution of the responses on the effect of cooperative membership on the level of entrepreneurial skills acquired by women.

\begin{tabular}{|c|c|c|c|}
\hline S/No & Effect of Cooperative Membership & Mean $(\overline{\mathbf{x}})$ & Decision \\
\hline i. & $\begin{array}{l}\text { Training on the production of soap } \\
\text { and cream }\end{array}$ & 3.65 & Effective \\
\hline ii. & $\begin{array}{l}\text { Skills on honey bee rearing and } \\
\text { processing }\end{array}$ & 4.22 & Effective \\
\hline iii. & $\begin{array}{l}\text { Tailoring and hair salon skills } \\
\text { programmes }\end{array}$ & 4.01 & Effective \\
\hline iv. & $\begin{array}{l}\text { Skills on palm oil processing and } \\
\text { production }\end{array}$ & 3.76 & Effective \\
\hline v. & $\begin{array}{l}\text { Skills on how to manage and establish } \\
\text { small scale business }\end{array}$ & 4.32 & Effective \\
\hline vi. & Catering services skills & 3.99 & Effective \\
\hline vii. & Garri processing and production skills & 4.33 & Effective \\
\hline viii. & Poultry and livestock business skills & 4.21 & Effective \\
\hline \multirow[t]{2}{*}{ ix. } & Fish farm and fish production skills & 4.26 & Effective \\
\hline & Grand Mean $(\bar{x})$ & 4.128 & Effective \\
\hline
\end{tabular}

Source: Field Survey October, 2014 


\subsection{Hypothesis Three $\left(\mathrm{H}_{03}\right)$}

$\mathrm{H}_{03:}$ There is no significant relationship between entrepreneurial skills acquired by women cooperators and cooperative economic empowerment activities.

$\mathrm{H}_{\mathrm{A} 3}$ : There is significant relationship between entrepreneurial skills acquired by women cooperators and cooperative economic empowerment activities.

Therefore, in order to affirm or reject the above stated hypothesis, the descriptive result table 4.2 and table 9 were subjected to non parametric correlations and the result is presented in the table below
Table 10. Comparism of Descriptive Statistics table 4 and 9.

\begin{tabular}{ll}
\hline Business Activities & Entrepreneurial skill \\
\hline 4.044 & 3.65 \\
4.050 & 4.22 \\
3.726 & 4.01 \\
3.714 & 3.76 \\
4.020 & 4.32 \\
3.880 & 4.53 \\
3.778 & 3.99 \\
3.714 & 4.33 \\
3.856 & 4.21 \\
4.108 & 4.26 \\
\hline
\end{tabular}

Table 11. Nonparametric Correlations Result table.

\begin{tabular}{lllll}
\hline Correlations & & & & \\
\hline & & & Activities & Skills acquired Entreprenuerial \\
\hline & & Correlation Coefficient & 1.000 & .134 \\
Spearman's rho & & Sig. (2-tailed) &. & .013 \\
& & $\mathrm{~N}$ & 10 & 10 \\
& Entrepreneurial & Correlation Coefficient & .134 & 1.000 \\
& & Sig. (2-tailed) & .013 &. \\
\hline
\end{tabular}

The correlation between the two factors is 1.000 which can be interpreted as perfect relationship and positive in nature. The correlation value is significant as the p-value of the test is less than 0.05 .

Conclusion: since the p-value of the test statistic is less than 0.05 , there exist enough evidence to reject the null hypothesis and conclude that there is significant relationship between women cooperatives economic empowerment activities and entrepreneurial skills acquisition of members.

\subsection{Women Income Level before and after Joining Women Cooperative Society}

Table 12. Distribution of responses on Annual Income Level Disparity of the respondents before and after their membership with women cooperative society.

\begin{tabular}{|c|c|c|c|c|}
\hline \multirow{2}{*}{$\begin{array}{l}\text { Women cooperator annual income level before and } \\
\text { after cooperative membership }\end{array}$} & \multicolumn{2}{|l|}{ Before } & \multicolumn{2}{|l|}{ After } \\
\hline & Frequencyn $=375$ & Percentage $(\%)$ & Frequencyn $=375$ & Percentage $(\%)$ \\
\hline Less than 50,000 & 108 & 28.8 & 41 & 10.93 \\
\hline $51,000-100,000$ & 136 & 36.26 & 54 & 14.4 \\
\hline $300,001-500,000$ & 31 & 8.26 & 124 & 33.06 \\
\hline $500,001-1$ million & 3 & 0.8 & 31 & 8.26 \\
\hline 1.1million -2 million & - & - & 16 & 4.266 \\
\hline Above 5million & - & - & - & - \\
\hline
\end{tabular}

Source: Field Survey October, 2014

Result from the above table 12 shows comparism between income levels of women cooperators before and after they joined cooperative society. It was deduced that, women annual income level increase significantly after they have join cooperative society.

This result also correlates with the result of study conducted by Smith and Wills (2012) and Aregawi and Haileslasie (2013) where they compared effect cooperative membership on women income before and after joining cooperative society and they found out that cooperative increase the income level of members by $50 \%$ and $39.8 \%$ respectively.

\subsection{Test of Hypothesis Four $\left(\mathrm{H}_{04}\right)$}

$\mathrm{H}_{04}$ : There is no significant disparity in annual income level of women cooperators when compared before and after their membership in cooperative society.
$\mathrm{H}_{\mathrm{A} 4}$ : There is significant disparity in annual income level of women cooperators when compared before and after their membership in cooperative society.

The formulated hypothesis was subjected to two sample Ttest and confidence interval test (before and after) and the result is present as follows:

Table 13. Disparity in the level of income before and after joining cooperative society.

\begin{tabular}{ll}
\hline Before & After \\
\hline 108 & 41 \\
136 & 54 \\
97 & 116 \\
31 & 124 \\
3 & 31 \\
0 & 16 \\
0 & 3 \\
0 & 0 \\
\hline
\end{tabular}


Table 14. Two-Sample T-Test and CI: Before, After.

\begin{tabular}{lllll}
\hline \multicolumn{5}{l}{ Two-sample T for Before vs After } \\
\hline & N & Mean & StDev & Mean \\
\hline Before & 9 & 41.7 & 55.3 & 18 \\
After & 9 & 41.7 & 55.0 & 18 \\
\hline
\end{tabular}

Difference $=\mathrm{mu}($ Before $)-\mathrm{mu}($ After $)$

Estimate for difference: 0.0

95\% CI for difference: $(-55.4,55.4)$

$\mathrm{T}$-Test of difference $=0$ (vs. not $=)$ : T-Value $=0.00 \mathrm{P}-$ Value $=1.000 \mathrm{DF}=15$

\subsection{Comment}

The p-value of .000 shows the existence of significant difference between the two groups. And since the P-value is less than 0.05 at $5 \%$ level of significance, the researcher reject null hypothesis and concluded that there is significant disparity in annual income level of women cooperators when compared before and after joining the comparative society.

These results of the hypothesis further strengthen the result of the descriptive statistics table 12 and the claim of Agregawi and Haileslasie (2013) and Smith and Will (2012).

\subsection{Constraints to Economic Empowerment Activities of Cooperatives}

Table 15. Distribution of responses on the constraints that limit economic empowerment efforts of women cooperative societies.

\begin{tabular}{|c|c|c|c|}
\hline S/No & Constraints & Mean $(\overline{\mathbf{x}})$ & Decision \\
\hline i. & Low literacy level among members & 2.53 & Disagree \\
\hline ii. & Cultural beliefs and sex stereotype & 3.45 & Agree \\
\hline iii. & Gender norms and gender inequality & 4.23 & Agree \\
\hline iv. & Location of members & 4.43 & Agree \\
\hline v. & $\begin{array}{l}\text { Limited fund to deliver empowerment } \\
\text { programmes }\end{array}$ & 4.56 & Agree \\
\hline vi. & $\begin{array}{l}\text { Lack of facilitators for empowerment } \\
\text { programmes to cooperative }\end{array}$ & 4.38 & Agree \\
\hline vii. & $\begin{array}{l}\text { Lack of government and community } \\
\text { support }\end{array}$ & 4.31 & Agree \\
\hline viii. & $\begin{array}{l}\text { Inactive participation among women } \\
\text { co-operators }\end{array}$ & 3.43 & Agree \\
\hline ix. & $\begin{array}{l}\text { Dishonesty, greed and corruption } \\
\text { among cooperative leaders }\end{array}$ & 3.58 & Agree \\
\hline $\mathrm{x}$. & $\begin{array}{l}\text { Poor management of cooperative } \\
\text { business }\end{array}$ & 3.65 & Agree \\
\hline xi. & $\begin{array}{l}\text { Ineffective and poor extension } \\
\text { services delivery }\end{array}$ & 4.11 & agree \\
\hline \multirow[t]{2}{*}{ xii. } & $\begin{array}{l}\text { Poor infrastructure/social amenities } \\
\text { that facilitates empowerment among } \\
\text { women }\end{array}$ & 4.33 & Agree \\
\hline & Grand Mean $(\bar{x})$ & 4.128 & Effective \\
\hline
\end{tabular}

Source: Field Survey October, 2014

Evidence from the above table 15 shows those women cooperative societies are being challenged with various constraints which ranged from cultural beliefs (3.45); gender inequality (4.23); limited fund (4.56); lack of support (4.31); ineffective and poor extension services delivery (4.11).

Therefore, the grand mean $(\overline{\mathrm{x}}=3.9158)$ affirmed that the constraints hamper the economic empowerment activities of women cooperative societies in Osun State.

\section{Conclusion and Recommendations}

The study examined that effect of cooperative membership on the economic empowerment of women in Osun State. As such, evidence from the findings revealed that;

1. Women cooperators are still in their active and productive stages $(\bar{x}=4$ years $)$ and most of them possessed basic educational qualifications while they are gainfully employed within the informal sectors. Also their socioeconomic profile is significant factor for their membership in cooperative society as most of their socioeconomic variables (age, education, marital status, experience income) are significant at 5\% level of significance while $\mathrm{P}$-value is less than 0.05 ;

2. From the result of the study $(\bar{x}=3.809)$ it was revealed that women cooperative societies in Osun State are involved in different economic empowerment activities that are accessible and capable of empowering women in Osun State. similarly it was revealed that women cooperators opinion are not differ significantly on these economic empowerment activities of their cooperatives $(\mathrm{P}$-value $=.222)$;

3 . The result of the study revealed that, there was enough evidence $(\bar{x}=4.128)$; $(\mathrm{P}$-value $=0.000)$ that economic empowerment activities of women cooperatives have effective and positive effects on the level of entrepreneurial skills acquired by the women cooperators in Osun State;

4. The findings from the study also revealed that being a member of cooperative society has positive effect on the income level of the members; and

5. Lastly, the women cooperative societies in Osun State are being challenges by different constraints e.g. inadequate fund for empowerment programme, poor extension service delivery etc and these constraints are capable of limiting optimum delivery of economic empowerment to women in Osun State.

\subsection{Conclusion}

Cooperatives are business owned and controlled by the people who use them and it is differ from other business because their member owned and operate for the benefit of members rather than making profits for the investors. As such cooperatives were organize on the basis of benefiting members in the following aspects which include improve bargaining power, improve income level, alleviate poverty, reduce cost, acquisition of skills, obtain products or services otherwise unavailable, expand new and existing marketing opportunities as well as improve product or service quality.

\subsection{Recommendations}

Therefore in order to encourage cooperative membership and strengthen economic empowerment activities of women cooperative societies, the following recommendations are made: 
1. The cooperative society should integrate adult education as part of their empowerment programmes. This will boost the literacy level of the women cooperators and increase their chances of getting social and economic inclusion. More so, it will help them to actively participate in decision making women ability in making productive economic decisions;

2. The cooperative should also seek for more innovative programmes that will boost economic status of women cooperators. The innovative programmes like modern livestock farm business, fish processing and production business etc. The innovative skills in livestock farm business, fish processing and production business etc, this will enable women to attain self reliance as well as boosting their self esteem;

3. Since increate income level is attributed to membership effect, as such cooperatives should encourage people to join the society also encourage members to actively participate in the economic activities of the society. This will not only boost their income but their participation will trickle down poverty alleviation and give them opportunity of having access to productive resources and bargaining power in which they could not ordinarily attain on their own; and

4. Finally, extension services delivery are key to effective economic empowerment. As such, the cooperative should provide quality extension servicedelivery that is capable of diffusing technology and innovations. Similarly, they shouldhire the services of competent facilitators that can impact skills to their members.

\section{References}

[1] Aregawi, T. and Haileslasie T. (2013). The Role of Cooperative in Promoting Socio-Economic Empowerment of Women: Evidence from Multipurpose Cooperative Societies in South-Eastern Zone of Tigray, Ethiopia. International Journal of Community Development Vo. 1, No. 1, 20131 111. DOI: $1011634 / 233028791301325$.

[2] Ask.com (2014). Theory of economic empowerment. Retrieved from http://www.answers.com

[3] Coopzone (2014). The Cooperative Advantage. Retrieved from htpp://coopzone.coop

[4] Duflo, E. (2012). Women Empowerment. Journal of Economic Literature, 50(4), 1051 - 1079. Retrieved from http://dx.org
[5] International Cooperative Alliance (1995). Statement on the Cooperative Identity. Retrieved from http://www.ka.coop

[6] Kabeer N. (2001). "Conflicts over Credit: Re-evaluating the Empowerment Potential of Loans to Women in Rural Bangladesh”, World Development, 29(1), pp. 63-84.

[7] Karubi, N. P. (2006). "Development, Micro-credit and Women's Empowerment: A Case Study of Market and Rural Women in Southern Nigeria", New Zealand: University of Canterbury.

[8] Nipperd, A. (2002). Gender Issues in Cooperatives. Geneva Switzerland International Labour Organization.

[9] Nussbaum, M.C. (2005). Women, Culture and Development: A Study of Human Capabilities. Oxford Clarendon Press.

[10] Oyeniyi, B. (2013). The Impact of Cooperative Society in Empowerment of Rural Women. Retrieved from http://kayworld-bukkyblegspot.

[11] World Bank (2003), "Poverty Analysis", [online] Available at http://www.worldbank.org/poverty/wdrpoverty/index.htm [Accessed 9 October, 2011]

[12] World Bank, Food and Agriculture Organization, and International Fund for Agricultural Development (2009), "Gender in Agriculture Sourcebook", Washington D.C: The World Bank.

[13] United Nations (2005). Progress towards the Millennium Development Goals, 1.990-2005. Secretary-Generals Millennium Development Goals Report. New York and Geneva: United Nations Publications.

[14] Wikipedia, The Free Encyclopedia (2014). Women in Cooperatives. Retrieved from http://en.wikipedia.org

[15] World Bank (2001). Engendering Development: Through Gender Equality in Rights, Resources, and Voice. New York and Oxford: Oxford University Press; Washington, D.C.: World Bank,

[16] World Bank (2011). World Development Report 2012: Gender Equality and Development. Washington, D.C.: World Bank.

[17] Chrissy King (2006). "Gender and Rural Community Development.

[18] Onugu, C.U and Ojiagu, N.C. (2009). Genderizing Development in Rural Nigeria: Needs Challenges and Approaches. Journal of legislative Studies 1(2), May - August 2009. 